\title{
Measuring the burden of arboviral diseases: the spectrum of morbidity and mortality from four prevalent infections
}

\author{
A Desirée LaBeaud ${ }^{1,2^{*}}$, Fatima Bashir ${ }^{1}$, Charles $\mathrm{H} \mathrm{King}^{2}$
}

\begin{abstract}
Background: Globally, arthropod-borne virus infections are increasingly common causes of severe febrile disease that can progress to long-term physical or cognitive impairment or result in early death. Because of the large populations at risk, it has been suggested that these outcomes represent a substantial health deficit not captured by current global disease burden assessments.
\end{abstract}

Methods: We reviewed newly available data on disease incidence and outcomes to critically evaluate the disease burden (as measured by disability-adjusted life years, or DALYs) caused by yellow fever virus (YFV), Japanese encephalitis virus (JEV), chikungunya virus (CHIKV), and Rift Valley fever virus (RVFV). We searched available literature and official reports on these viruses combined with the terms "outbreak(s)," "complication(s)," "disability," "quality of life," "DALY," and "QALY," focusing on reports since 2000. We screened 210 published studies, with 38 selected for inclusion. Data on average incidence, duration, age at onset, mortality, and severity of acute and chronic outcomes were used to create DALY estimates for 2005, using the approach of the current Global Burden of Disease framework.

Results: Given the limitations of available data, nondiscounted, unweighted DALYS attributable to YFV, JEV, CHIKV, and RVFV were estimated to fall between 300,000 and 5,000,000 for 2005. YFV was the most prevalent infection of the four viruses evaluated, although a higher proportion of the world's population lives in countries at risk for CHIKV and JEV. Early mortality and long-term, related chronic conditions provided the largest DALY components for each disease. The better known, short-term viral febrile syndromes caused by these viruses contributed relatively lower proportions of the overall DALY scores.

Conclusions: Limitations in health systems in endemic areas undoubtedly lead to underestimation of arbovirus incidence and related complications. However, improving diagnostics and better understanding of the late secondary results of infection now give a first approximation of the current disease burden from these widespread serious infections. Arbovirus control and prevention remains a high priority, both because of the current disease burden and the significant threat of the re-emergence of these viruses among much larger groups of susceptible populations.

\section{Background}

Arthropod-borne viral infections, or arboviral infections, are common causes of disabling fever syndromes worldwide, but their cumulative impact on global disease burden has not been fully assessed. In their acute stages, arboviral infections cause a broad spectrum of disease,

\footnotetext{
* Correspondence: alabeaud@chori.org

${ }^{1}$ Center for Immunobiology and Vaccine Development, Children's Hospital

Oakland Research Institute, Oakland, California, USA

Full list of author information is available at the end of the article
}

ranging from asymptomatic infection to severe undifferentiated fever. They can also progress to much more complex secondary conditions, or sequelae, such as encephalitis or hemorrhagic diathesis, which result in long-term physical and cognitive impairment or in early death $[1,2]$.

More than 100 arboviruses are known to cause disease in humans. A significant subset, including members of the Flaviviridae, Bunyaviridae, and Togaviridae families, are transmitted widely in different areas of

\section{Biomed Central}


the world (Figure 1). As threats to public health, these viruses are best known for their propensity to cause encephalitis and/or viral hemorrhagic fever (VHF) syndromes [1-4]. Arboviruses are also considered to be emerging pathogens based on their geographic spread and their increasing impact on susceptible human populations [5-14]. As an example, dengue virus (DENV) infections, once rare, are now estimated to cause $>50$ million clinical cases per year following a resurgence in Asia and renewed spread through Central and South America [15].

As with other tropical diseases, the disabling sequelae of arboviruses disproportionately affect resourcepoor communities through chronic impairment of individual performance in activities of daily living [16]. Long-term longitudinal studies of the impact of childhood arbovirus infections remain few in number, particularly for post-encephalitic complications, meaning that the lifetime burden of these infections is not well understood [17-19]. Of note, it is not just the severe forms of acute arbovirus-related illness but also the nominally milder forms of arboviral infection that can result in long-lasting impairment, as has been best described for neurologic and ophthalmologic complications of West Nile virus (WNV) infection [20-26]. Frequent neurological impairment, lasting weeks to years, has now also been recognized in association with chikungunya virus (CHIKV) and dengue infection [2]. Less well known are the medium- to long-term (months to years duration) ocular complications that can occur after arboviral infection. Rift Valley fever virus (RVFV) [27-32], WNV [33-39], DENV [40-47], and CHIKV [48-51] all cause inflammatory ophthalmologic complications, including chorioretinitis, uveitis, iridocyclitis, and optic neuritis. With WNV, when such post-infectious, long-term sequelae occur, most patients recover within the two years following the onset of illness [52-54]. However, this is not the case for Japanese encephalitis virus (JEV) infection, in which post-encephalitic neurologic injury and disability are most often permanent $[55,56]$. Newer evidence also suggests that CHIKV infection can also cause significant physical and mental impairment for $>30$ months after infection [57]. At present, only the disease burden caused by dengue and JEV infections are included in World Health Organization (WHO) Global Burden of Disease (GBD) estimates [58]. For other arboviruses, any significant cause-specific early mortality or any long-term infection-related morbidity (particularly as a lifetime effect of childhood disease) represent a substantial health deficit not currently captured by disease burden assessments, and hence are not included in top-level discussions of disease control priorities [58-61].

\section{Yellow Fever}

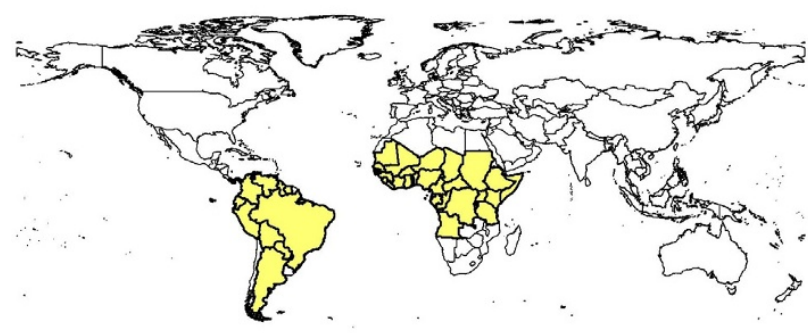

\section{Chikungunya}
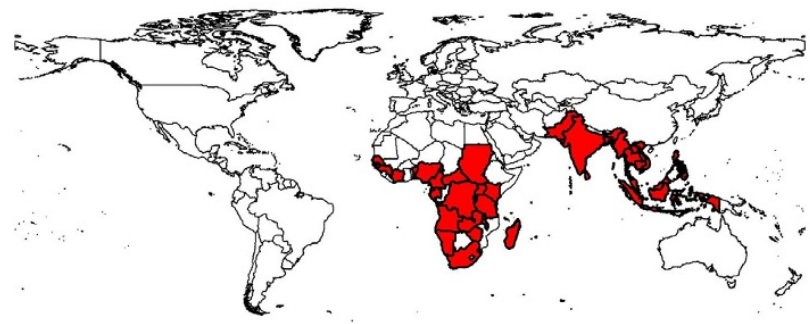

\section{Japanese Encephalitis}

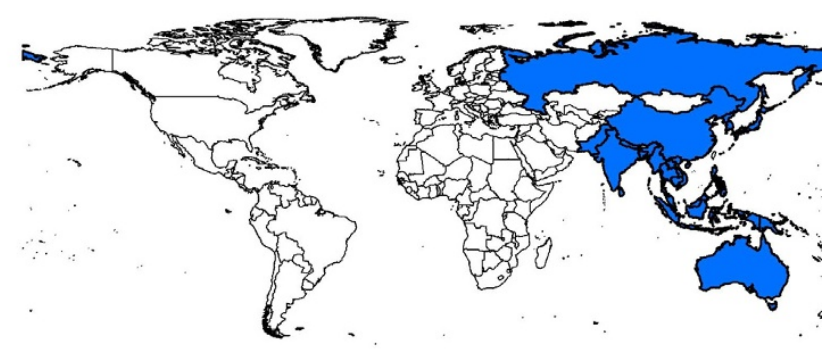

\section{Rift Valley Fever}

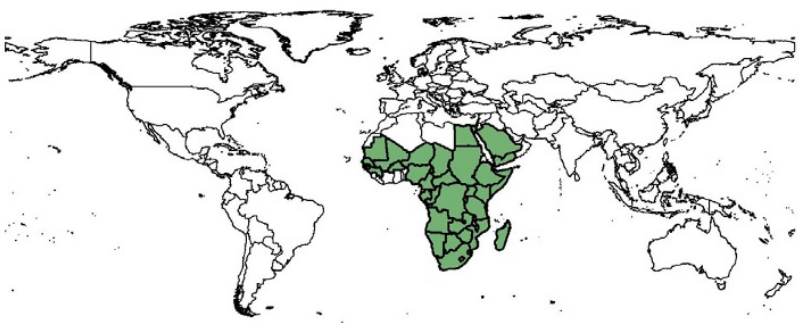

Figure 1 Countries having transmission of the four arthropod-borne viruses included in this study: yellow fever virus, Japanese encephalitis virus, chikungunya virus, and Rift Valley fever virus. 
As new evidence has emerged in the past decade on the frequency of arboviral infections and the incidence of their long-term, disabling sequelae [17-37,39-54,62], it is now appropriate to revisit the global estimates of the health impact of these infections. In this paper, our aim is to review the available evidence on incidence and disease duration and critically compare the estimated disease burden measured in disability-adjusted life years (DALYs) caused by four common arboviral infections:

1) Yellow fever (YFV), a disease with very high acute mortality due to hemorrhagic complications [63];

2) Japanese encephalitis (JEV), having high rates of both acute mortality and very long-term neurologic disability $[55,56,64]$;

3) Chikungunya virus (CHIKV) fever, a disease with low mortality but high rates of post-infectious rheumatologic and neurologic morbidity $[48,65,66]$;

4) Rift Valley fever (RVFV), having intermediate rates of mortality and of long-term ocular and neurologic morbidity $[28,30,31,67,68]$.

\section{Methods}

\section{Setting for the analysis}

In deriving our disease burden assessments for the arboviruses under study, we chose to develop DALY estimates for the disease comparisons presented in this paper. To do so, we incorporated the following assumptions:

- The population of interest is the 2005 world population, listed by country, as quantified according to the estimates given in the United States Census Bureau's International Database (http://www.census. gov/ipc/www/idb/index.php).

- The global and regional disease burden of each study disease is measurable in DALYs, developed as previously described in WHO and World Bank publications [59] and modified by the Disease Control Priorities Project [61].

- DALY scores for each condition represent the sum of two components: a) for cases of mortality, the years of healthy life lost (YLL) from a standard expected years of life lost (SEYLL), plus b) for individuals having nonlethal, disease-specific disability, the years lived with disability times a disability weight reflecting the proportion of impairment caused by that health condition (YLD) [69].

- Different from the original DALY concept [69], which employed age-weighting, and in accord with more recent usage [60], we report both $3 \%$ time-discounted, unweighted DALYs (indicated as DALY $(3,0))$ and nondiscounted, unweighted DALYs (indicated as DALY $(0,0))$ for each condition. [See [69] for a detailed discussion on age-weighting and discounting.] Our intention is to make the current estimates align with contemporary discussions of global health risks and the Global Burden of Disease (http:// www.who.int/healthinfo/global_burden_disease/en/ index.html).

\section{Data collection}

DALY summary calculations rely on the best available, evidence-based estimates of yearly incidence, mortality, average age at death, and, for nonlethal cases, information on the duration and impact (disability weight) of cause-specific disability outcomes related to the disease. We searched the available published literature and official reports on YFV, JEV, CHIKV and RVFV, focusing on the years since 2000. In order to capture the impact of endemic disease, we excluded studies and reports of disease among travelers from nonendemic areas. Searching was initiated with the use of the arbovirus name and the terms "outbreaks," "complications," "disability," "quality of life," "DALY," and "QALY" in PubMed and Google Scholar, and continued with hand searching of bibliographies of the selected publications. Each publication or report was evaluated by two authors, and the relevant information was extracted. Publications had to meet three inclusion criteria: 1) discussion of complications that lead to mortality or prolonged morbidity; 2) focus on population-based information, including incidence and/or prevalence; and 3) published after 2000. We screened 210 published studies, of which 38 were selected for inclusion. Additional tables and charts from US Centers for Disease Control and Prevention and WHO publications were included in the data collection.

\section{DALY calculations}

Nondiscounted and time-discounted DALY estimates for each disease were calculated according to standard methods (but with only uniform age weighting [69]) using spreadsheets developed by the authors. Because of limitations in the available data (see Results), our summary estimates were calculated for both sexes together, and not distributed according to age group, as ideally presented in DALY tables $[59,60]$. Additionally, we present our DALY estimates as a range of credible values based on uncertainties or potential variability of the input values. The range of inputs for incidence of symptomatic cases, associated case fatality, median age at death, and duration of post-infection disability were taken from the included reports.

Disability weights (DW) for acute JEV disease and chronic sequelae were taken from Murray and Lopez [59] and Mathers et al. [58] (Table 1). For the other study arboviruses, the range of DWs for severe acute febrile illness were based on published estimates for 
Table 1 Sources for disability weight estimates of arbovirus-related long-term morbidities: Proxy values based on Global Burden of Disease project disability weights for analogous health states

\begin{tabular}{|c|c|c|c|}
\hline Arbovirus & Sequelae details and expected prevalence & $\begin{array}{l}\text { Analogous morbidity DW from } \\
\text { GBD project listings [59] }\end{array}$ & $\begin{array}{l}\text { DW input range } \\
\text { for YLD } \\
\text { estimations }\end{array}$ \\
\hline $\begin{array}{l}\text { Yellow fever } \\
\text { (YFV) }\end{array}$ & $\begin{array}{l}\text { Zero to } 2 \% \text { of YFV survivors who require critical care for severe } \\
\text { hemorrhage or acute encephalopathy can expect protracted symptoms } \\
\text { ranging from mild cognitive impairment to severe disability [79] }\end{array}$ & $\begin{array}{l}\text { Persisting mild cognitive } \\
\text { impairment } \approx \text { malnutrition, DW }= \\
0.024 \\
\text { Severe psychomotor deficits } \approx \\
\text { severe complications of JEV, DW }= \\
0.616\end{array}$ & $0.02-0.62$ \\
\hline $\begin{array}{l}\text { Japanese } \\
\text { encephalitis } \\
\text { (JEV) }\end{array}$ & $30 \%$ to $50 \%$ of survivors can expect severe neurologic disability $[72,83]$ & $\begin{array}{l}\text { JEV-associated moderate cognitive } \\
\text { impairment up to severe disability } \\
\text { [59] }\end{array}$ & $0.39-0.49$ \\
\hline $\begin{array}{l}\text { Chikungunya } \\
\text { (CHIKV) }\end{array}$ & $\begin{array}{l}5 \% \text { to } 50 \% \text { of survivors will have prolonged post-infectious } \\
\text { rheumatologic and neurologic complications }[57,85,86]\end{array}$ & $\begin{array}{l}\approx \text { Osteoarthritis, DW }=0.156 \\
\text { or } \\
\approx \text { Rheumatoid arthritis, DW }=0.233\end{array}$ & $0.16-0.23$ \\
\hline $\begin{array}{l}\text { Rift Valley } \\
\text { fever (RVFV) }\end{array}$ & $\begin{array}{l}4 \% \text { to } 10 \% \text { of survivors develop prolonged ocular and neurologic } \\
\text { complications of ophthalmitis and meningoencephalitis }[27,67]\end{array}$ & $\begin{array}{l}\text { Prolonged visual impairment } \approx \\
\text { trachoma, DW }=0.223 \\
\text { Severe psychomotor deficits } \approx \\
\text { severe complications of JEV, DW }= \\
0.616\end{array}$ & $0.22-0.62$ \\
\hline
\end{tabular}

Abbreviations: GBD, Global Burden of Diseases; DW, disability weight; YLD, Years lived with disability.

analogous acute viral syndromes that were ranked in the original GBD framework, i.e., dengue (DW $=0.172$ $0.211)$ or JEV (DW = 0.616) [59]. DWs for chronic neurological and visual impairment sequelae of the studied arbovirus infections were based on closely analogous syndromes ranked within the GBD framework, i.e., those for post-encephalitic cognitive impairment (DW = 0.469-0.485) and other neurologic sequelae (DW = 0.388-0.468) listed for JEV, for lameness after poliomyelitis $(\mathrm{DW}=0.369)$, and for infection-related blindness $(\mathrm{DW}=0.600)$ or low vision $(0.223-0.245)$ following trachoma [59] (see Table 1).

\section{Note on incidence estimates for arbovirus infections}

Arbovirus infections typically occur in epidemics. Due to seasonal and weather-related changes in arthropodborne transmission of arboviruses and periodic fluctuations in the number of susceptible humans within an area $[70,71]$, there may be significant variation in the local, regional, and global number of cases from year to year. Nevertheless, for planning purposes and for creation of comparable DALY estimates, it is important to estimate an annualized number of affected cases, as presented in the Results. It is also recognized that, for some arboviruses, only a small fraction of infected humans will become clinically symptomatic $[72,73]$. For this reason, our annualized incidence rates, case-fatality rates, and acute-to-chronic-disease case conversion rates are based on reported or informed estimates of the numbers of clinical cases of arbovirus-related symptomatic disease, and not on serologic evidence of local arbovirus transmission to humans (see schema in Figure 2). Although during epidemic periods, clinical case rates may reach 10-150 per 100,000 in a national population $[1,71,74,75]$, over a period of one to three decades, annualized human disease incidence rates for symptomatic cases from the study arboviruses typically occur in the range of 0.2 per year per 100,000 general population (RVFV in East Africa $[27,76])$, to 2.4 per year per 100,000 general population (for JEV [77]).

Final DALY calculations based on 2005 estimates were as follows:

DALY $=$ YLL $+\mathrm{YLD}_{\text {acute }}+\mathrm{YLD}_{\text {chronic }}$, where

$\mathrm{YLL}=$ (Incident deaths) $\times$ (standard expected years of life lost at median age of death)

$\mathrm{YLD}_{\text {acute }}=($ Incident cases with acute disease only $) \times$ $\mathrm{DW}_{\text {acute }} \times($ duration acute disease $)$

$\mathrm{YLD}_{\text {chronic }}=($ Incident cases progressing to chronic disease $) \times \mathrm{DW}_{\text {chronic }} \times$ (duration of chronic disease $)$. For calculation of DALY $(3,0)$ estimates, $3 \%$ per annum time-discounting was applied to future SEYLL and disease duration values.

\section{Sensitivity analysis}

Because of substantial uncertainty about a number of parameters involved in the DALY calculation for each study arbovirus, we were unable to provide a "base case" for subsequent sensitivity analysis. Instead, we present what we believe is the most credible range for possible DALY burdens for each virus and discuss the implications for health planning assessments. 


\section{Susceptible population}

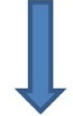

Transmission study

Infected $\longrightarrow$ Not symptomatic

(no related disability)

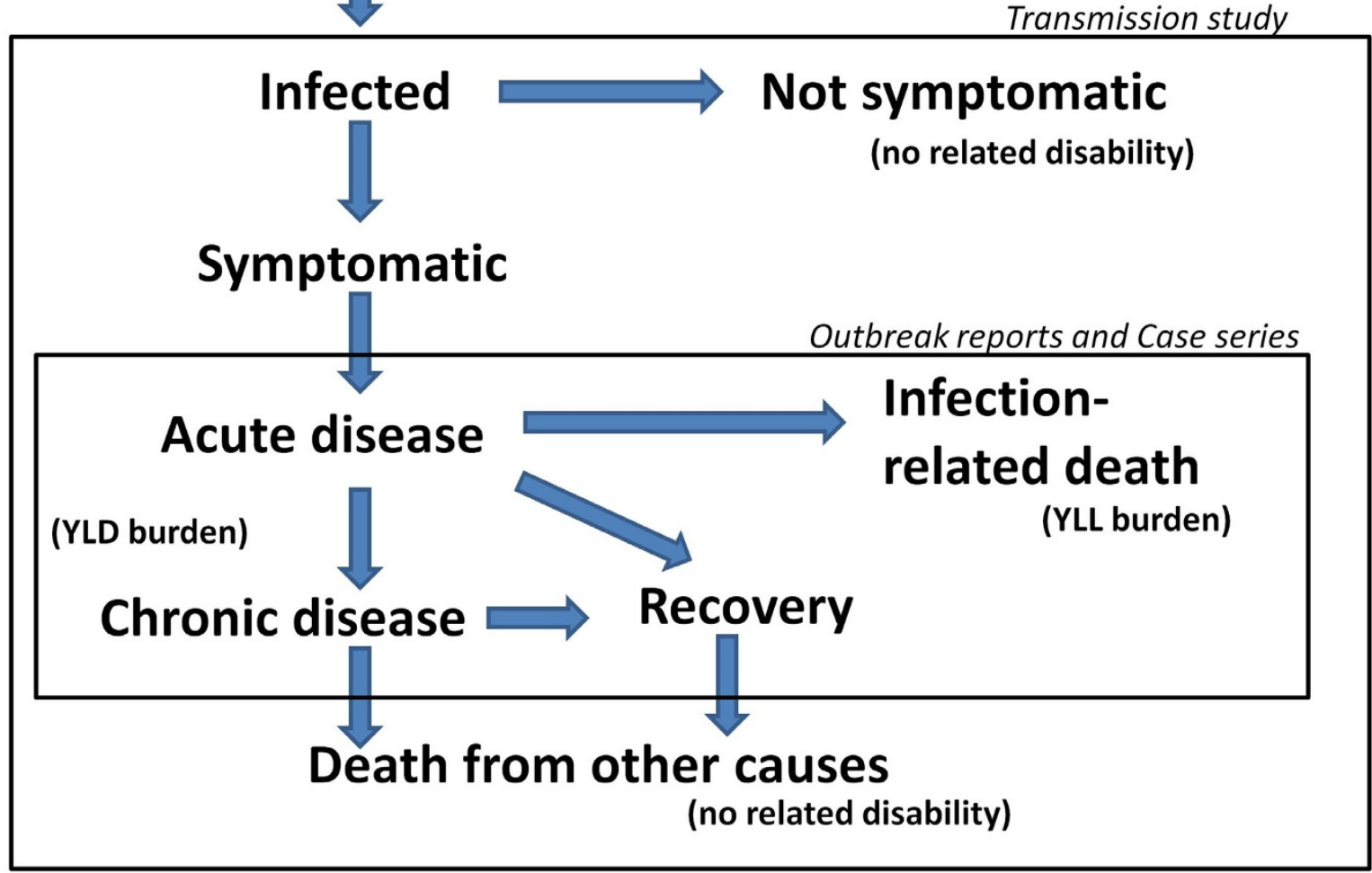

Figure 2 Schema of disease development and assessment of population-level disease parameters for arboviral infections. Among a general population, susceptible (nonimmune) persons who are exposed to the bite of infected/infectious arthropods will go on to develop infection, which may become symptomatic or remain nonsymptomatic. Transmission studies, usually based on serologic testing, provide evidence of past and present infections among the target population, but do not quantify human disease or disability. Symptomatic disease (acute and chronic) and causespecific fatality may be tallied either actively (by public health outbreak investigations) or passively (by health care systems statistics or case series reports). The generalizability of the rates reported for complications (transition to chronic disease) and for arbovirus-related fatality can vary widely depending on the sampling frame, study design, duration of longitudinal follow-up, and accuracy of diagnostics used.

\section{Results}

Global distribution of disease

Table 2 and Figure 1 summarize the global distribution of the four study arboviruses. Included are estimates of the populations living in affected countries, along with estimates of annualized average cause-specific mortality rates and incidence of chronic disease cases due to the four arbovirus infections.

Table 3 summarizes information abstracted by our literature review regarding the estimated average number

Table $\mathbf{2}$ World population affected by study arboviruses

\begin{tabular}{|c|c|c|c|c|}
\hline Arbovirus & $\begin{array}{l}\text { Number of affected } \\
\text { countries }\end{array}$ & $\begin{array}{l}\text { Population in endemic countries (\% of global } \\
\text { population) }\end{array}$ & $\begin{array}{c}\text { Estimated deaths per } \\
\text { year }\end{array}$ & $\begin{array}{c}\text { Chronic cases per } \\
\text { year }^{a}\end{array}$ \\
\hline Yellow fever & 44 & $972,155,287(15 \%)$ & $675-30,000$ & 0 to 1,955 \\
\hline $\begin{array}{l}\text { Japanese } \\
\text { encephalitis }\end{array}$ & 23 & $3,706,910,037(57 \%)$ & 3,500 to 15,000 & 7,350 to 22,500 \\
\hline Chikungunya & 41 & $2,548,842,950(39 \%)$ & 33 to 25,761 & 1,193 to 46,453 \\
\hline Rift Valley fever & 32 & $778,528,381(12 \%)$ & 4 to 91 & 12 to 272 \\
\hline
\end{tabular}

\footnotetext{
${ }^{a}$ Note: These are annualized averages over combined epidemic and interepidemic periods.
} 
Table 3 DALY inputs: Average annualized incidence, typical age at onset, mortality, and risk for disability for studied pathogens

\begin{tabular}{|c|c|c|c|c|}
\hline $\begin{array}{l}\text { Arbovirus name (common } \\
\text { abbreviation) }\end{array}$ & $\begin{array}{l}\text { Estimated clinical cases }{ }^{\mathrm{a}} \\
\text { per annum }{ }^{\mathrm{b}}\end{array}$ & $\begin{array}{l}\text { Median age for } \\
\text { symptomatic disease }\end{array}$ & $\begin{array}{l}\text { Case-fatality } \\
\text { rate }(\%)^{c}\end{array}$ & $\begin{array}{l}\text { Survivor's risk for multiyear or } \\
\text { permanent disability }\end{array}$ \\
\hline Yellow fever (YFV) & 30,000 to $200,000[78]$ & $25 \mathrm{yr}[80,81]$ & $\begin{array}{l}2 \text { to } 15 \% \\
{[78,79,81]}\end{array}$ & 0 to $2 \%[78]$ \\
\hline Japanese encephalitis (JEV) & 35,000 to $50,000[72,82]$ & 10 yr [72] & $\begin{array}{l}10 \text { to } 30 \% \\
{[72,82]}\end{array}$ & 30 to $50 \%[72,83]$ \\
\hline Chikungunya (CHIKV) & 33,000 to $93,000^{b}$ & $40 \mathrm{yr}[84,88]$ & $\begin{array}{l}0.1 \text { to } 28 \% \\
{[75,84]}\end{array}$ & 5 to $50 \%[85,86]$ \\
\hline Rift Valley fever (RVFV) & 350 to $2,750^{b}$ & 28 yr $[68,104]$ & $\begin{array}{l}1 \text { to } 3.3 \% \\
{[32,74]}\end{array}$ & 4 to $10 \%[27,31]$ \\
\hline
\end{tabular}

${ }^{a}$ Clinical cases are defined as symptomatic cases requiring medical attention. Asymptomatic or inapparent infections are not included in these figures.

${ }^{b}$ Arbovirus transmission typically occurs in epidemic waves based on cyclical weather phenomena that contribute to significant increases in local abundance of arthropod vectors. For standardized DALY comparison, where global estimates of case rates were not available, the study assumed an annualized arboviral clinical case rate of 1.3 to $3.7 / 100,000$ in the general population of an at-risk country.

' Rate per clinical cases (see note a, above).

of incident clinical cases of arbovirus infection-related disease each year, along with the median age of onset for symptomatic disease, the range or reported casefatality rates (per symptomatic case), and estimates of the risk for progression to multiyear or permanent disability following the onset of symptomatic illness due to infection. Evidence from the available literature suggests that YFV may be the most prevalent infection of the four viruses evaluated, in part because of declines in YFV control efforts over the last several decades [78,79], and in part due to the success of JEV vaccination programs that have reduced the annual number of worldwide JEV cases to 50,000 or fewer [72].

To summarize specific findings of the literature review regarding the individual study viruses:

YFV is associated with high acute mortality related to its recognized potential to progress to its toxic phase and hemorrhagic fever in $15 \%$ to $25 \%$ of early symptomatic cases [79]. This advanced form of disease has $20 \%$ to $50 \%$ mortality [78-80]. During outbreaks, the median age of patients is between 20 and 30 years old [1,81], and the duration of acute illness is typically 18 to 21 days overall. Symptoms of infection are high fever, chills, headache, muscle aches, vomiting, and backache, indicating an acute disability in the range of that for dengue hemorrhagic fever or acute JEV infection (DW $=0.2$ to 0.6). Because the toxic phase of infection can lead to shock, bleeding, kidney and liver failure, and the need for several weeks of critical care, we also postulate a possible $10 \%$ incidence of long-term disabling complications after successful recovery from this critical form of the disease. In other words, about $1 \%$ to $2 \%$ of all nonlethal symptomatic YFV infections are estimated to result in chronic disabling disease.

JEV has a high acute mortality rate (10\% to $30 \%)$ $[72,82]$ and for survivors, it frequently causes long-lasting morbidity due to complex neurological complications
$[72,83]$. The median age of patients is less than 10 years old among unvaccinated populations, with the majority of deaths occurring in this phase of childhood [83]. The duration of acute, nonlethal disease (DW $=0.616$ ) is two to three weeks. Although some motor deficits and movement disorders improve after the acute illness, 30\% to $50 \%$ of JEV survivors have long-term neurologic or psychiatric sequelae $[72,83]$. These include seizures, upper and lower motor neuron weakness, cerebellar and extrapyramidal signs, flexion deformities of the arms, hyperextension of the legs, cognitive deficits, language impairment, learning difficulties, and behavioral problems. These late outcomes of JEV infection are probably permanent and have been rated at $\mathrm{DW}=0.388$ to 0.485 by the Global Burden of Disease project $[59,60]$.

CHIKV infection has lower mortality among the general population (1 per 1,000) [75], but higher mortality (14\% to $30 \%)$ among hospitalized cases with neurological complications [84]. Symptomatic acute infection is associated with neurological, renal, cardiac, respiratory, hepatic, and hematological complications, with a high risk for long term (> 30 mos) rheumatologic complications among patients older than 30 years $[57,85,86]$. Those patients affected by long-term, chronic symptoms after CHIKV infection reported significant persistent pain and impairment of activities of daily living [57,87], with resulting decreased quality of life as measured by formal testing $[57,85]$. For this post-chikungunya syndrome, we and others [88] have chosen to use DW values of 0.11 to 0.23 as analogous to values for chronic arthritides in the Global Burden of Disease framework $[59,60]$.

RVFV is associated with a wide range of morbidities. Human RVFV infection is considered to be nearly always symptomatic $[89,90]$, typically presenting as a syndrome of fever with nausea and arthralgias [68], 
sometimes progressing to meningoencephalitis (10\%) $[32,67,68]$, uveitis/retinitis $(10 \%$ to $30 \%)[27,31]$, or hemorrhagic diathesis ( $1 \%$ to $3 \%$ ) that is highly fatal $[32,67,68]$. Average age of symptomatic disease is between 20 and 30 years [68,76]. Average duration of acute RVFV infection is one to two weeks, while late neurological and visual complications are most likely lifelong [27,67]. Disability from these late complications was considered to be analogous to the severe neurological sequelae of JEV or its cognitive impairment (DW = 0.39 and 0.47 , respectively), and to low vision (DW = 0.22 ) or blindness (DW $=0.60$ ) from trachoma.

Table 4 indicates the range of calculated global 2005 DALY estimates for each study virus based on the information summarized above. Because of variability in estimates for the incidence of the study arboviruses and the conditional probability of death or chronic complications after acute disease, we calculated a range of DALY values for each pathogen based on an annualized average number of symptomatic cases each year. Our results indicate a probable range for the aggregate, nondiscounted, uniformly weighted DALY $(0,0)$ burden equal to 307,082 to $5,057,081$ DALYs, and a $3 \%$ discounted, uniformly weighted DALY $(3,0)$ of 127,681 to $2,385,203$ for these pathogens combined for the world population.

\section{Discussion}

The four arboviral infections were chosen to highlight the broad range of their associated mortality and shortand long-term disability. The estimates presented here extend earlier work on the DALY impact of arboviral infections on global health [60]. Our combined 2005 DALY $(3,0)$ estimates of 127,681 to $2,385,203$, based on disease and mortality rates taken from published research and official reports, are in line with previously published estimates for dengue $(529,000$ DALYs $(3,0))$ and for JEV $(604,000$ DALYs $(3,0))$ for 2001. The variation between estimates indicates the difficulty of deriving precise point estimates for these diseases based on currently available data [58]. Data were limited for ageand sex-specific case rates and for the likelihood of chronic sequelae from these four arboviral infections. Often, data were collected only during outbreaks, and therefore, interepidemic transmission of these infections was not included. Despite these limitations, the findings suggest a persistent, nonnegligible world disease burden due to arboviral disease that requires further attention in research and public health agendas.

Perceptions about the actual frequency of arboviral disease are changing. As better diagnostics are introduced in at-risk areas, more accurate case finding allows for better definition of the risk of symptomatic disease and the long-term sequelae of infection [91,92]. Inherent in the DALY calculations, it is YLL from cause-specific mortality and the years lived with long-term, advanced disability that provide the largest proportion of DALY values associated with these conditions. Careful, multiyear longitudinal follow-up (as reported for WNV in the US $[20-22,24,25,93])$ will be needed to define these rates more accurately.

Misclassification in diagnosis has also played a role in the underestimation of viral disease burden. Arbovirus infections are common causes of severe disease but mimic other infections, such as acute malaria, and are frequently misdiagnosed as such $[4,94]$. Better diagnosis and careful post-mortem studies indicate that a

Table 4 Calculated global 2005 DALY estimates for the four study viruses-yellow fever, Japanese encephalitis, chikungunya, and Rift Valley fever, based on data from previous tables

\begin{tabular}{|c|c|c|c|c|c|c|}
\hline \multicolumn{7}{|c|}{2005 Nondiscounted DALYs $(0,0)$} \\
\hline Arbovirus & 2005 YLLs & 2005 YLDs & 2005 DALYs $(0,0)^{a}$ & YLLs per death & YLDs per acute case & YLDs per chronic case \\
\hline Yellow fever & $38,475-1,710,000$ & $303-73,704$ & $38,827-1,774,049$ & 57 & $0.012-0.024$ & $1.43-35.3$ \\
\hline Japanese encephalitis & $252,000-1,080,000$ & $13,660-1,002,006$ & $265,778-1,859,170$ & 72 & $0.012-0.024$ & $1.43-44.5$ \\
\hline Chikungunya & $1,386-1,081,962$ & $405-456,898$ & $2,124-1,411,904$ & $2-42$ & $0.012-0.024$ & $0.22-9.79$ \\
\hline Rift Valley fever & $192-4,901$ & $158-7,236$ & $353-11,958$ & 42 & $0.006-0.06$ & $12.6-26$ \\
\hline Total & $292,053-3,876,863$ & $14,526-1,539,844$ & $307,082-5,057,081$ & - & - & - \\
\hline \multicolumn{7}{|c|}{2005 Discounted DALYs $(3,0)$} \\
\hline Arbovirus & 2005 YLLs & 2005 YLDs & 2005 DALYs $(3,0)^{a}$ & YLLs per death & YLDs per acute case & YLDs per chronic case \\
\hline Yellow fever & $18,225-810,000$ & $303-37,732$ & $18,577-842,769$ & 27 & $0.012-0.024$ & $0.55-16.9$ \\
\hline Japanese encephalitis & $101,500-435,000$ & $4,557-412,506$ & $107,435-755,670$ & 29 & $0.012-0.024$ & $0.6-18.3$ \\
\hline Chikungunya & $759-592,503$ & $394-260,399$ & $1,481-780,234$ & 23 & $0.012-0.024$ & $0.21-5.56$ \\
\hline Rift Valley fever & $96-2,450$ & $90-4,186$ & $188-6,530$ & 27 & $0.006-0.06$ & $7.16-14.8$ \\
\hline Total & $120,580-1,839,953$ & $5,344-714,823$ & $127,681-2,385,203$ & - & - & - \\
\hline
\end{tabular}

${ }^{a}$ NOTE: Total DALY min and max do not sum across the YLL and YLD rows above because gains in one DALY category column (e.g., YLL) are necessarily offset by reductions in survival and reduction in possible YLDs. 
significant minority (23\%) of WHO-defined "cerebral malaria" cases can be due to other infectious and noninfectious causes [95]. As true malaria prevalence wanes with successful prevention and treatment campaigns, arboviruses are poised to become the most frequent cause of severe febrile illness throughout the world. As shown in Figure 1 and Table 2, many countries and a large segment of the world's population are at risk for arboviral transmission. Of special note, malaria control programs using insecticide-treated bed nets and indoor residual spraying are not a panacea for arbovirus control. Though the night-biting Anopheles vectors of malaria are strongly affected by household-based interventions, many arboviruses are transmitted by daytimefeeding Aedes mosquitoes or by outdoor Culex spp. mosquitoes. Thus, arbovirus transmission often occurs outside the home while at work or in the market $[79,96]$, meaning that very different interventions are needed for arbovirus vector control.

Arboviruses also have very important impacts outside the sphere of human health. An aspect of public health that cannot be assessed in the DALY system is the epidemic potential of most arboviral pathogens. While the DALY estimates reflect a "steady-state" assessment of disease burden in a given era, the highly unpredictable demands of arbovirus epidemics compel the need for policy planning regarding the provision of health care surge capacity, the prevention of economic and political disruption, and the blunting of the loss of food production due to zoonotic disease in arbovirus prevention and control. Although the current estimated clinical cases (Table 3) and DALY estimates (Table 4) may seem small when averaged per year over the world's population, substantial economic losses and health care disruption often result from a severe arboviral outbreak in a given region [97]. For example, once RVFV is known to be circulating in an animal herd, the World Organisation for Animal Health (OIE) places a three-year export embargo on those animals. The embargo is economically devastating to that farm and region, already suffering from the health consequences of the RVFV outbreak. The political, psychological, and economic implications of reporting arbovirus outbreaks may also contribute to intentional underreporting of these diseases.

As the world becomes increasingly networked through globalization and as vectors and viruses continue to evolve, infections that were once contained in remote tropical locations are likely to spread to new areas. Just as WNV emerged in the United States in 1999, other arboviral pathogens may escape control to infect large susceptible populations [7,98-101]. Recent examples include WNV [14] and chikungunya [102,103]. Because no specific medical treatment exists for most arboviral infections, continuing public health surveillance for vector-borne infections and continuing vector control (outside the standard health care delivery systems) are crucial to prevent these diseases and the morbidity and mortality that result from them. Likewise, vaccine development for arboviruses remains a priority because of their outbreak potential. Recent evidence suggests a surge in YFV cases due to the decline in YFV control and vaccination efforts, highlighting the precarious dominance we have over these infections and the immediate increase in disease burden resulting from lack of persistent focus on surveillance and control $[78,79]$. Ultimately, due to the externalities of arbovirus outbreaks, the development of new arboviral vaccines for common pathogens, such as dengue, may prove extremely costeffective in terms of economic costs, even if their DALY impact is more modest.

\section{List of abbreviations}

CDC: U.S. Centers for Disease Control and Prevention; CHIKV: Chikungunya virus; DALY: Disability-adjusted life year; DENV: Dengue virus; DW: Disability weight; JEV: Japanese encephalitis virus; RVFV: Rift Valley fever virus; SEYLL: Standard expected years of life lost; VHF: Viral hemorrhagic fever syndrome; WHO: World Health Association; WNV: West Nile virus; YFV: Yellow fever virus; YLL: Years of life lost; YLD: Years lived with disability

\section{Acknowledgements}

Drs. LaBeaud and King are supported by the Midwest Research Center of Excellence in Biodefense (funded by the US National Institute of Allergy and Infectious Diseases through grant \#U54 Al057160). The funders did not play any role in the study design, data collection, analysis, or interpretation of the results, nor did they participate in the preparation of this manuscript work or the decision to publish this work.

\section{Author details}

${ }^{1}$ Center for Immunobiology and Vaccine Development, Children's Hospital Oakland Research Institute, Oakland, California, USA. ${ }^{2}$ Center for Global Health and Diseases, Case Western Reserve University, Cleveland, Ohio, USA

\section{Authors' contributions}

Authors ADL and CHK were involved in the conception and design of the project, the acquisition of data, and their analysis and interpretation. Both were involved in drafting the manuscript and revision for content. Author FB had substantial participation in the acquisition and archiving of data and was involved in drafting the manuscript. All authors have given approval of the final version of the paper.

\section{Competing interests}

The authors declare that they have no competing interests.

Received: 16 July 2010 Accepted: 10 January 2011

Published: 10 January 2011

\section{References}

1. CDC Viral Hemorrhagic Fevers Fact Sheet. [http://www.cdc.gov/ncidod/ dvrd/spb/mnpages/dispages/vhf.htm], accessed March 29, 2010.

2. CDC Arboviral Encephalitides Fact Sheet. [http://www.cdc.gov/ncidod/ dvbid/Arbor/index.htm], accessed July 12, 2010.

3. Gould EA, Solomon T: Pathogenic flaviviruses. Lancet 2008, 371:500-509.

4. Sang RC, Dunster LM: The growing threat of arbovirus transmission and outbreaks in Kenya: a review. East Afr Med J 2001, 78:655-661.

5. Gubler D: The emergence of epidemic dengue fever and dengue hemorrhagic fever in the Americas: a case of failed public health policy. Rev Panam Salud Publica 2005, 17:221-224. 
6. Gubler DJ: Dengue and dengue hemorrhagic fever. Clin Microbiol Rev 1998, 11:480-496.

7. Gubler DJ: The global emergence/resurgence of arboviral diseases as public health problems. Arch Med Res 2002, 33:330-342.

8. Gubler DJ: Epidemic dengue/dengue hemorrhagic fever as a public health, social and economic problem in the 21st century. Trends Microbiol 2002, 10:100-103.

9. Gubler DJ, Clark GG: Dengue/dengue hemorrhagic fever: the emergence of a global health problem. Emerg Infect Dis 1995, 1:55-57.

10. Gubler DJ, Meltzer M: Impact of dengue/dengue hemorrhagic fever on the developing world. Adv Virus Res 1999, 53:35-70.

11. Lundstrom JO: Mosquito-borne viruses in western Europe: a review. $J$ Vector Ecol 1999, 24:1-39.

12. Mackenzie JS, Gubler DJ, Petersen LR: Emerging flaviviruses: the spread and resurgence of Japanese encephalitis, West Nile and dengue viruses. Nat Med 2004, 10:S98-109.

13. Mackenzie JS, Johansen CA, Ritchie SA, van den Hurk AF, Hall RA: Japanese encephalitis as an emerging virus: the emergence and spread of Japanese encephalitis virus in Australasia. Curr Top Microbiol Immunol 2002, 267:49-73.

14. Nash D, Mostashari F, Fine A, Miller J, O'Leary D, Murray K, Huang A, Rosenberg A, Greenberg A, Sherman M, et al: The outbreak of West Nile virus infection in the New York City area in 1999. N Engl J Med 2001, 344:1807-1814.

15. W.H.O. Dengue and dengue haemorrhagic fever fact sheet. No. 117 March 2009. [http://www.who.int/mediacentre/factsheets/fs117/en/]

16. LaBeaud AD: Why arboviruses can be neglected tropical diseases. PLoS Negl Trop Dis 2008, 2:e247.

17. LaBeaud AD, Lisgaris MV, King CH, Mandalakas AM: Pediatric West Nile virus infection: neurologic disease presentations during the 2002 epidemic in Cuyahoga County, Ohio. Pediatr Infect Dis J 2006, 25:751-753.

18. Robin S, Ramful D, Le Seach F, Jaffar-Bandjee MC, Rigou G, Alessandri JL: Neurologic manifestations of pediatric chikungunya infection. $J$ Child Neurol 2008, 23:1028-1035.

19. Balkhy HH, Schreiber JR: Severe La Crosse encephalitis with significant neurologic sequelae. Pediatr Infect Dis J 2000, 19:77-80

20. Carson PJ, Konewko P, Wold KS, Mariani P, Goli S, Bergloff P, Crosby RD: Long-term clinical and neuropsychological outcomes of West Nile virus infection. Clin Infect Dis 2006, 43:723-730.

21. Klee AL, Maidin B, Edwin B, Poshni I, Mostashari F, Fine A, Layton M, Nash D: Long-term prognosis for clinical West Nile virus infection. Emerg Infect Dis 2004, 10:1405-1411.

22. Ou AC, Ratard RC: One-year sequelae in patients with West Nile Virus encephalitis and meningitis in Louisiana. J La State Med Soc 2005, 157:42-46.

23. Sejvar JJ, Haddad MB, Tierney BC, Campbell GL, Marfin AA, Van Gerpen JA, Fleischauer A, Leis AA, Stokic DS, Petersen LR: Neurologic manifestations and outcome of West Nile virus infection. JAMA 2003, 290:511-515.

24. Sejvar JJ, Bode AV, Marfin AA, Campbell GL, Pape J, Biggerstaff BJ, Petersen LR: West Nile Virus-associated flaccid paralysis outcome. Emerg Infect Dis 2006, 12:514-516.

25. Sejvar JJ: The long-term outcomes of human West Nile virus infection. Clin Infect Dis 2007, 44:1617-1624

26. Watson JT, Pertel PE, Jones RC, Siston AM, Paul WS, Austin CC, Gerber Sl: Clinical characteristics and functional outcomes of West Nile Fever. Ann Intern Med 2004, 141:360-365

27. LaBeaud AD, Muchiri EM, Ndzovu M, Mwanje MT, Muiruri S, Peters CJ, King CH: Interepidemic Rift Valley fever virus seropositivity, northeastern Kenya. Emerg Infect Dis 2008, 14:1240-1246.

28. Siam AL, Gharbawi KF, Meegan JM: Ocular complications of Rift Valley fever. J Egypt Public Health Assoc 1978, 53:185-186.

29. Siam AL, Meegan J: Ocular disease resulting from infection with Rift Valley fever virus. Trans R Soc Trop Med Hyg 1980, 74:539.

30. Siam AL, Meegan JM, Gharbawi KF: Rift Valley fever ocular manifestation: observations during the 1977 epidemic in the Arab Republic of Egypt. British Journal of Ophthalmology 1980, 64:366-374.

31. Al-Hazmi A, Al-Rajhi AA, Abboud EB, Ayoola EA, Al-Hazmi M, Saadi R, Ahmed N: Ocular complications of Rift Valley fever outbreak in Saudi Arabia. Ophthalmology 2005, 112:313-318.

32. Al-Hazmi M, Ayoola EA, Abdurahman M, Banzal S, Ashraf J, El-Bushra A, Hazmi A, Abdullah M, Abbo H, Elamin A, et al: Epidemic Rift Valley fever in
Saudi Arabia: a clinical study of severe illness in humans. Clin Infect Dis 2003, 36:245-252.

33. Anninger W, Lubow M: Visual loss with West Nile virus infection: a wider spectrum of a "new" disease. Clin Infect Dis 2004, 38:e55-56.

34. Anninger WV, Lomeo MD, Dingle J, Epstein AD, Lubow M: West Nile virusassociated optic neuritis and chorioretinitis. Am J Ophthalmol 2003, 136:1183-1185.

35. Eidsness RB, StockI F, Colleaux KM: West Nile chorioretinitis. Can J Ophthalmol 2005, 40:721-724

36. Hershberger VS, Augsburger JJ, Hutchins RK, Miller SA, Horwitz JA, Bergmann M: Chorioretinal lesions in nonfatal cases of West Nile virus infection. Ophthalmology 2003, 110:1732-1736.

37. Khairallah M, Ben Yahia S, Ladjimi A, Zeghidi H, Ben Romdhane F, Besbes L, Zaouali S, Messaoud R: Chorioretinal involvement in patients with West Nile virus infection. Ophthalmology 2004, 111:2065-2070

38. Khairallah M, Yahia SB, Letaief M, Attia S, Kahloun R, Jelliti B, Zaouali S, Messaoud R: A prospective evaluation of factors associated with chorioretinitis in patients with West Nile virus infection. Ocul Immunol Inflamm 2007, 15:435-439.

39. Koevary SB: Ocular involvement in patients infected by the West Nile virus. Optometry 2005, 76:609-612

40. Bacsal KE, Chee SP, Cheng CL, Flores JV: Dengue-associated maculopathy. Arch Ophthalmol 2007, 125:501-510.

41. Gupta A, Srinivasan R, Setia S, Soundravally R, Pandian DG: Uveitis following dengue fever. Eye (Lond) 2009, 23:873-876.

42. Kapoor HK, Bhai S, John M, Xavier J: Ocular manifestations of dengue fever in an East Indian epidemic. Can J Ophthalmol 2006, 41:741-746.

43. Lim WK, Mathur R, Koh A, Yeoh R, Chee SP: Ocular manifestations of dengue fever. Ophthalmology 2004, 111:2057-2064.

44. Mehta S, Jiandani P: Ocular features of dengue septic shock (DSS). J Assoc Physicians India 2006, 54:866.

45. Nah G, Tan M, Teoh S, Chong CH: Maculopathy associated with Dengue fever in a military pilot. Aviat Space Environ Med 2007, 78:1064-1067

46. Seet RC, Quek AM, Lim EC: Symptoms and risk factors of ocular complications following dengue infection. J Clin Virol 2007, 38:101-105.

47. Su DH, Bacsal K, Chee SP, Flores JV, Lim WK, Cheng BC, Jap AH: Prevalence of dengue maculopathy in patients hospitalized for dengue fever. Ophthalmology 2007, 114:1743-1747

48. Lalitha P, Rathinam S, Banushree K, Maheshkumar S, Vijayakumar R, Sathe P: Ocular involvement associated with an epidemic outbreak of chikungunya virus infection. Am J Ophthalmol 2007, 144:552-556.

49. Mittal A, Mittal S, Bharati MJ, Ramakrishnan R, Saravanan S, Sathe PS: Optic neuritis associated with chikungunya virus infection in South India. Arch Ophthalmol 2007, 125:1381-1386.

50. Mittal A, Mittal S, Bharathi JM, Ramakrishnan R, Sathe PS: Uveitis during outbreak of Chikungunya fever. Ophthalmology 2007, 114:1798.

51. Mahendradas P, Ranganna SK, Shetty R, Balu R, Narayana KM, Babu RB, Shetty BK: Ocular manifestations associated with chikungunya. Ophthalmology 2008, 115:287-291.

52. Yim R, Posfay-Barbe KM, Nolt D, Fatula G, Wald ER: Spectrum of clinical manifestations of West Nile virus infection in children. Pediatrics 2004 114:1673-1675

53. Bjorn G: Victims of West Nile virus face long-term health problems. Nat Med 2008, 14:700

54. Murray KO, Baraniuk S, Resnick M, Arafat R, Kilborn C, Shallenberger R, York TL, Martinez D, Malkoff M, Elgawley N, et al: Clinical investigation of hospitalized human cases of West Nile virus infection in Houston, Texas, 2002-2004. Vector Borne Zoonotic Dis 2008, 8:167-174.

55. Gould EA, Solomon T, Mackenzie JS: Does antiviral therapy have a role in the control of Japanese encephalitis? Antiviral Res 2008, 78:140-149

56. Solomon T, Kneen R, Dung NM, Khanh VC, Thuy T, Ha DQ, Day NP, Nisalak A, Vaughn DW, White NJ: Poliomyelitis-like illness due to Japanese encephalitis virus. Lancet 1998, 351:1094-1097.

57. Marimoutou C, Vivier E, Simon F: Long-lasting overmorbidity and impaired quality of life 30 months after chikungunya infection: Comparative cohort of French gendarmes exposed to chikungunya in 2006 in Reunion Island [abstract 376]. American Society of Tropical Medicine and Hygiene 59th Annual Meeting; Atlanta, Georgia. Am J Trop Med Hyg 2010, 109 . 
58. Mathers CD, Ezzati M, Lopez AD: Measuring the burden of neglected tropical diseases: the global burden of disease framework. PLoS Negl Trop Dis 2007, 1:e114.

59. Murray CJL, Lopez AD: The Global Burden of Disease: A comprehensive assessment of mortality and disability from diseases, injuries, and risk factors in 1990 and projected to 2020. Cambridge MA: Harvard School of Public Health/World Bank; 1996

60. Lopez AD, Mathers CD, Ezzati M, Jamison DT, Murray CJ: Global Burden of Disease and Risk Factors. Washington DC: World Bank; 2006

61. Jamison DT, Breman JG, Measham AR, Alleyne G, Claeson M, Evans DB, Jha P, Mills A, Musgrove P, (Eds): Disease Control Priorities in Developing Countries 2/e. New York: Oxford University Press; 2006

62. Khairallah M, Ben Yahia S, Attia S, Zaouali S, Ladjimi A, Messaoud R: Linear pattern of West Nile virus-associated chorioretinitis is related to retinal nerve fibres organization. Eye (Lond) 2007, 21:952-955

63. Sanders EJ, Marfin AA, Tukei PM, Kuria G, Ademba G, Agata NN, Ouma JO, Cropp CB, Karabatsos N, Reiter P, et al: First recorded outbreak of yellow fever in Kenya, 1992-1993. I. Epidemiologic investigations. Am J Trop Med Hyg 1998, 59:644-649.

64. Lowry PW, Truong DH, Hinh LD, Ladinsky JL, Karabatsos N, Cropp CB, Martin D, Gubler DJ: Japanese encephalitis among hospitalized pediatric and adult patients with acute encephalitis syndrome in Hanoi, Vietnam 1995. Am J Trop Med Hyg 1998, 58:324-329.

65. Borgherini G, Poubeau P, Staikowsky F, Lory M, Le Moullec N, Becquart JP, Wengling C, Michault A, Paganin F: Outbreak of chikungunya on Reunion Island: early clinical and laboratory features in 157 adult patients. Clin Infect Dis 2007, 44:1401-1407.

66. Staples JE, Breiman RF, Powers AM: Chikungunya fever: an epidemiological review of a re-emerging infectious disease. Clin Infect Dis 2009, 49:942-948.

67. Riou O, Philippe B, Jouan A, Coulibaly I, Mondo M, Digoutte JP: [Neurologic and neurosensory forms of Rift Valley fever in Mauritania]. Bull Soc Pathol Exot Filiales 1989, 82:605-610.

68. Kahlon SS, Peters CJ, Leduc J, Muchiri EM, Muiruri S, Njenga MK, Breiman RF, Clinton White A Jr, King CH: Severe Rift Valley fever may present with a characteristic clinical syndrome. Am J Trop Med Hyg 2010, 82:371-375.

69. Murray CJ: Rethinking DALYs. In The Global Burden of Disease. Edited by: Murray CJ, Lopez AD. Cambridge MA: Harvard School of Public Health/ World Bank; 1996:1-98.

70. Anderson RM, May RM: Infectious Diseases of Humans. Dynamics and Control. New York: Oxford University Press; 1991

71. Mudur G: Failure to control mosquitoes has led to two fever epidemics in India. BMJ 2006, 333:773.

72. Fischer M, Lindsey N, Staples JE, Hills S: Japanese encephalitis vaccines: recommendations of the Advisory Committee on Immunization Practices (ACIP). MMWR Recomm Rep 2010, 59:1-27.

73. Mandalakas AM, Kippes C, Sedransk J, Kile JR, Garg A, McLeod J, Berry RL, Marfin AA: West Nile virus epidemic, northeast Ohio, 2002. Emerg Infect Dis 2005, 11:1774-1777.

74. Woods CW, Karpati AM, Grein T, McCarthy N, Gaturuku P, Muchiri E, Dunster L, Henderson A, Khan AS, Swanepoel R, et al: An outbreak of Rift Valley Fever in Northeastern Kenya, 1997-98. Emerging Infectious Diseases 2002, 8:138-144.

75. Charrel RN, de Lamballerie X, Raoult D: Chikungunya outbreaks-the globalization of vectorborne diseases. N Engl J Med 2007, 356:769-771.

76. Woods CW, Karpati AM, Grein T, McCarthy N, Gaturuku P, Muchiri E, Dunster L, Henderson A, Khan AS, Swanepoel R, et al: An outbreak of Rift Valley fever in Northeastern Kenya, 1997-98. Emerg Infect Dis 2002, 8:138-144

77. Kari K, Liu W, Gautama K, Mammen MP Jr, Clemens JD, Nisalak A, Subrata K, Kim HK, Xu ZY: A hospital-based surveillance for Japanese encephalitis in Bali, Indonesia. BMC Med 2006, 4:8

78. Mutebi JP, Barrett AD: The epidemiology of yellow fever in Africa. Microbes Infect 2002, 4:1459-1468.

79. Monath TP: Yellow fever: an update. Lancet Infect Dis 2001, 1:11-20

80. Gould LH, Osman MS, Farnon EC, Griffith KS, Godsey MS, Karch S, Mulenda B, El Kholy A, Grandesso F, de Radigues X, et al: An outbreak of yellow fever with concurrent chikungunya virus transmission in South Kordofan, Sudan, 2005. Trans R Soc Trop Med Hyg 2008, 102:1247-1254.

81. Ribeiro M, Antunes CM: [Yellow fever: study of an outbreak]. Rev Soc Bras Med Trop 2009, 42:523-531.

82. Solomon T, Dung NM, Kneen R, Gainsborough M, Vaughn DW, Khanh VT: Japanese encephalitis. J Neurol Neurosurg Psychiatry 2000, 68:405-415.

83. Hossain MJ, Gurley ES, Montgomery S, Petersen L, Sejvar J, Fischer M, Panella A, Powers AM, Nahar N, Uddin AK, et al: Hospital-based surveillance for Japanese encephalitis at four sites in Bangladesh, 20032005. Am J Trop Med Hyg 2010, 82:344-349.

84. Tandale BV, Sathe PS, Arankalle VA, Wadia RS, Kulkarni R, Shah SV, Shah SK Sheth JK, Sudeep AB, Tripathy AS, Mishra AC: Systemic involvements and fatalities during chikungunya epidemic in India, 2006. J Clin Virol 2009, 46:145-149.

85. Soumahoro MK, Gerardin P, Boelle PY, Perrau J, Fianu A, Pouchot J, Malvy D, Flahault A, Favier F, Hanslik T: Impact of chikungunya virus infection on health status and quality of life: a retrospective cohort study. PLoS One 2009, 4:e7800.

86. Borgherini G, Poubeau P, Jossaume A, Gouix A, Cotte L, Michault A, ArvinBerod C, Paganin F: Persistent arthralgia associated with chikungunya virus: a study of 88 adult patients on Reunion Island. Clin Infect Dis 2008, 47:469-475.

87. de Andrade DC, Jean S, Clavelou P, Dallel R, Bouhassira D: Chronic pain associated with the Chikungunya Fever: long lasting burden of an acute illness. BMC Infect Dis 2010, 10:31.

88. Seyler T, Hutin Y, Ramanchandran V, Ramakrishnan R, Manickam P, Murhekar M: Estimating the burden of disease and the economic cost attributable to chikungunya, Andhra Pradesh, India, 2005-2006. Trans $R$ Soc Trop Med Hyg 2010, 104:133-138.

89. Meegan JM, Hoogstraal H, Moussa MI: An epizootic of Rift Valley fever in Egypt in 1977. Vet Rec 1979, 105:124-125.

90. Peters CJ, Liu CT, Anderson GW Jr, Morrill JC, Jahrling PB: Pathogenesis of viral hemorrhagic fevers: Rift Valley fever and Lassa fever contrasted. Rev Infect Dis 1989, 11(Suppl 4):S743-749.

91. Njenga MK, Paweska J, Wanjala R, Rao CY, Weiner M, Omballa V, Luman ET, Mutonga $D$, Sharif S, Panning $M$, et al: Using a field quantitative real-time PCR test to rapidly identify highly viremic Rift Valley fever cases. J Clin Microbiol 2009, 47:1166-1171.

92. Anyangu AS, Gould LH, Sharif SK, Nguku PM, Omolo J, Mutonga D, Rao CY, Lederman E, Schnabel DC, Paweska JT, et al: Risk factors for severe Rift Valley fever infection in Kenya, 2007. Am J Trop Med Hyg 2010, 83(Suppl 2):14-21

93. Sejvar JJ, Leis AA, Stokic DS, Van Gerpen JA, Marfin AA, Webb R, Haddad MB, Tierney BC, Slavinski SA, Polk JL, et al: Acute flaccid paralysis and West Nile virus infection. Emerg Infect Dis 2003, 9:788-793.

94. Shears P: Emerging and reemerging infections in Africa: the need for improved laboratory services and disease surveillance. Microbes Infect 2000, 2:489-495

95. Taylor TE, Fu WJ, Carr RA, Whitten RO, Mueller JS, Fosiko NG, Lewallen S, Liomba NG, Molyneux ME: Differentiating the pathologies of cerebral malaria by postmortem parasite counts. Nat Med 2004, 10:143-145.

96. Vazquez-Prokopec GM, Stoddard ST, Paz-Soldan V, Morrison AC, Elder JP, Kochel TJ, Scott TW, Kitron U: Usefulness of commercially available GPS data-loggers for tracking human movement and exposure to dengue virus. Int J Health Geogr 2009, 8:68.

97. Winter-Nelson A, Rich KM: Mad cows and sick birds: financing international responses to animal disease in developing countries. Development Policy Review 2008, 26:211-226.

98. Hales $S$, Weinstein P, Woodward A: Public health impacts of global climate change. Rev Environ Health 1997, 12:191-199.

99. Githeko AK, Lindsay SW, Confalonieri UE, Patz JA: Climate change and vector-borne diseases: a regional analysis. Bull World Health Organ 2000, 78:1136-1147.

100. Patz JA, Lindsay SW: New challenges, new tools: the impact of climate change on infectious diseases. Curr Opin Microbiol 1999, 2:445-451.

101. Shope R: Global climate change and infectious diseases. Environ Health Perspect 1991, 96:171-174. 
102. Powers AM, Logue CH: Changing patterns of chikungunya virus: reemergence of a zoonotic arbovirus. J Gen Virol 2007, 88:2363-2377.

103. Schuffenecker I, Iteman I, Michault A, Murri S, Frangeul L, Vaney MC, Lavenir R, Pardigon N, Reynes JM, Pettinelli F, et al: Genome microevolution of chikungunya viruses causing the Indian Ocean outbreak. PLoS Med 2006, 3:e263

104. LaBeaud AD, Ochiai Y, Peters CJ, Muchiri EM, King CH: Spectrum of Rift Valley fever virus transmission in Kenya: insights from three distinct regions. Am J Trop Med Hyg 2007, 76:795-800.

doi:10.1186/1478-7954-9-1

Cite this article as: LaBeaud et al:: Measuring the burden of arboviral diseases: the spectrum of morbidity and mortality from four prevalent infections. Population Health Metrics 2011 9:1.

Submit your next manuscript to BioMed Central and take full advantage of:

- Convenient online submission

- Thorough peer review

- No space constraints or color figure charges

- Immediate publication on acceptance

- Inclusion in PubMed, CAS, Scopus and Google Scholar

- Research which is freely available for redistribution

Submit your manuscript at www.biomedcentral.com/submit 